\title{
Crop Production in the Haor Areas of Bangladesh: Insights from Farm Level Survey
}

\author{
M. Shahe Alam*, M.A. Quayum and M. A. Islam \\ Agricultural Economics Division, Bangladesh Rice Research Institute, Gazipur-1701, Bangladesh \\ *Corresponding author and Email:msalam_07@yahoo.com
}

Received: 07 March $2010 \quad$ Accepted: 17 March 2011

\begin{abstract}
A study was conducted in the haor areas of Bangladesh to assess the land utilization status, delineate the productivity and profitability of growing modern rice, evaluate the existing cropping patterns and assess the prospect of possible cropping patterns. Both primary and secondary data were used in the study. Applying the conventional descriptive statistics, the study revealed that, there are about 1.26 million hectares of cultivated lands in seven haor districts, of which $66 \%$ falls under haor area. In Kishoregonj and Hobigonj, nearly 94 and $87 \%$ areas were devoted to MV Boro rice production. Both BRRI dhan 28 and 29 were being the widely adopted rice varieties. On an average, about $33 \%$ of the haor areas were under mechanized irrigation, but in Kishoregonj, the coverage of mechanized irrigation was $87 \%$ that helped increasing cropping intensity. The cost of production for MV Boro was almost double than that of LV rice. The yield of MV Boro was 79\% higher than that of LVs and the return from MVs was $82 \%$ higher. Rabi-Fallow-T. Aman, Vegetable-Aus-T. Aman and Rabi-B.Aman patterns were the potential cropping patterns in some selected areas and this could increase both cropping intensity and productivity in those areas. According to the farmers' assessment, lack of flood control dam and lack of short duration varieties etc. are the major hindrance to the adoption of potential cropping patterns. Construction of community harvest and threshing facilities and flood control devices could be the important public interventions for enhanced agricultural productivity in the haor areas.
\end{abstract}

Key words: Haor areas, potential pattern, productivity, mechanization, profitability,

\section{Introduction}

There are many haors (basin like structure) where water remains either stagnant or in flash flooding condition during the months of June to November and mainly Boro rice is grown in the Rabi season using irrigation. Geographically, most of the haors are situated in seven districts of the North-East Bangladesh. The districts are: Sunamganj, Kishoreganj, Netrokona, Sylhet, Habiganj, Maulavibazar and B. Baria. There are as many as 423 small or large haors in Bangladesh. The Hakaloki haor, Sumir haor, Dakhar haor, Tanguyar haor, Gungiajuri haor, Mukhar haor, Kaowadighir haor etc are the prominent haors in Bangladesh. In terms of eco- system, crop production practices, economic activities and over all livelihood of the farmers of haor areas are quite different from those of the other parts of the country. The cropping practices particularly Boro rice crop mainly depends on nature. Early flood, hailstorm and drought are the main constraints to grow modern boro rice. The available statistics indicate that, the total cultivated area in those haor districts is about 1.26 million hectares of which 0.68 million ha (nearly 66\%) is under haor. Almost $80 \%$ of this area (i.e. 0.68 million ha) is covered by Boro rice, while only about $10 \%$ area is covered by $\mathrm{T}$. Aman production (Huda, 2004). In the haor areas, hybrid rice is also grown (Das, 2004). This 
area is gradually increasing in different locations of haor districts (Husain et al., 2001). So, there is a great possibility of growing MV rice as well as other rice and non-rice crops in the haor areas.

Since the cropped land area is being continuously shrinking over time leading to serious challenge towards increasing productivity and thus to the mission of attaining self-sufficiency in food production for the land scarce economy of Bangladesh, it has indeed become imperative to exploit the crop production potentiality of the large haor areas; it is because those areas usually remain under-utilized with quite low cropping intensity (Jabber and Alam, 1996). However, very limited study has been conducted with regards to delineating the issues of crop production practices in the haor areas. Therefore, a study was undertaken to understand the over all land utilization pattern and to know the constraints to MV rice cultivation and the prospect of possible improved cropping patterns in the haor areas of Bangladesh.

The specific objectives of the study were as follows:

i). to understand the land utilization pattern and assess the level of adoption of modern rice varieties in the selected haor areas of Bangladesh,

ii). to delineate the productivity and profitability of growing modern Boro rice in the haor areas,

iii). to evaluate the existing cropping patterns and assess the prospect of possible improved patterns ; and

iv). to ascertain the constraints to MV rice cultivation in the haor areas and derive policy implications from the study.

\section{Methodology}

Both primary and secondary data were used for the study. In selecting the study locations, multistage sampling technique was followed. At first, seven haor districts namely, Sunamganj, Kishoreganj, Netrokona, Sylhet, Habiganj, Maulavibazar and B. Baria were purposively selected. Seven upazilla (taking one upazilla under each of those districts) were also purposively selected. Then one village under each upazilla was selected randomly. From a comprehensive list of farm households in the village, forty sample farms from each village were selected for data collection following random sampling technique. Data were generated using structured questionnaire. In total 280 sample farmers in the haor areas were selected under the study. Data were generated through directly interviewing the sample farmers during Boro season of 2008-09. Necessary secondary data were collected from different published reports of Bangladesh Bureau of Statistics (BBS) and Department of Agriculture Extension (DAE). Mainly descriptive statistics were employed in analyzing the data.

To examine the mean differences for different items of input use, productivity and profitability between modern and indigenous rice production in the haor areas, T-test was employed.

The mean test was done employing the following formula;

$t=\frac{\bar{x}_{1}-\bar{x}_{2}}{\sqrt{\frac{s_{1}^{2}}{n_{1}}+\frac{s_{2}^{2}}{n_{2}}}}$

Where,

$$
\begin{aligned}
& S_{1}{ }^{2}=\frac{1}{n_{1}-1} \sum\left(X_{i 1}-\bar{X}\right)^{2} \\
& S_{2}{ }^{2}=\frac{1}{n_{2}-1} \sum\left(X_{j 2}-\bar{X}\right)^{2}
\end{aligned}
$$

\section{Results and Discussions}

\subsection{Magnitude of haor areas and land utilization scenario}

There are seven districts where there are as many as 423 haors. The highest number of haors (133) 
fall in Sunamganj district followed by Kishoregonj (122). The total cultivated land in those seven districts is 1.26 million hectares of which $66 \%$ area is covered by the haors (Table 1). However, about $88 \%$ of the total area under those seven districts fall under rice cropped area (DAE, 2008). The highest rice cropped area stands in Brahmanbaria while the lowest is in Moulavibazar follwed by Sunamgonj district.
It is interesting to note that, almost $100 \%$ haor area of Habiganj district is under cultivation. In Kishoregonj and Sunamgonj districts 80 and $78 \%$ of the haor areas are under crop cultivation, respectively. On the other, hand in Moulavibazar and B. Baria only 22 and $33 \%$ of the haor areas are under cultivation, respectively implying that there is enough scope of increasing rice crop area and thus increasing rice cropping intensity in those haor areas.

Table 1. Distribution of cultivated land under seven haor districts of Bangladesh, 2008 (Huda, 2004)

\begin{tabular}{|c|c|c|c|c|c|}
\hline \multirow[b]{2}{*}{ District } & \multirow[b]{2}{*}{ No. of haor* } & \multirow{2}{*}{$\begin{array}{l}\text { Total } \\
\text { cultivated land } \\
\text { (million ha) }\end{array}$} & \multirow{2}{*}{$\begin{array}{l}\text { Land area } \\
\text { under haor } \\
\text { (million ha ) }\end{array}$} & \multicolumn{2}{|c|}{ Cultivated land under haor } \\
\hline & & & & (million ha ) & $\begin{array}{c}\% \text { of haor } \\
\text { area }\end{array}$ \\
\hline Sunamgonj & 133 & 0.20 & 0.18 & 0.14 & 78 \\
\hline Kishoregonj & 122 & 0.17 & 0.15 & 0.12 & 80 \\
\hline Netrokona & 80 & 0.21 & 0.14 & 0.09 & 61 \\
\hline Sylhet & 43 & 0.21 & 0.05 & 0.03 & 60 \\
\hline Hobigonj & 38 & 0.19 & 0.04 & 0.04 & 100 \\
\hline Moulvi Bazar & 4 & 0.13 & 0.09 & 0.02 & 22 \\
\hline B. Baria & 3 & 0.15 & 0.03 & 0.01 & 33 \\
\hline Total & 423 & 1.26 & 0.68 & 0.45 & 66 \\
\hline
\end{tabular}

*The Jugantar, 18 April 2008

Table 2. Land use pattern and cropping intensity in the haor districts, 2008.

\begin{tabular}{|c|c|c|c|c|c|}
\hline \multirow[b]{2}{*}{ District } & \multirow{2}{*}{$\begin{array}{c}\text { Total } \\
\text { cropped area } \\
(000 \mathrm{ha})\end{array}$} & \multicolumn{3}{|c|}{$\%$ of cropped area under } & \multirow{2}{*}{$\begin{array}{c}\text { Cropping } \\
\text { intensity } \\
(\%)\end{array}$} \\
\hline & & Single cropping & $\begin{array}{l}\text { Double } \\
\text { cropping }\end{array}$ & $\begin{array}{c}\text { Triple } \\
\text { cropping }\end{array}$ & \\
\hline Sunamgonj & 397 & 44 & 23 & 3 & 143 \\
\hline Kishoregonj & 232 & 14 & 25 & 12 & 215 \\
\hline Netrokona & 424 & 15 & 29 & 8 & 186 \\
\hline Sylhet & 357 & 28 & 30 & 4 & 160 \\
\hline Hobigonj & 295 & 27 & 27 & 7 & 171 \\
\hline Moulvi Bazar & 221 & 22 & 32 & 5 & 171 \\
\hline B. Baria & 280 & 18 & 29 & 8 & 189 \\
\hline
\end{tabular}

DAE, (2008-2009) 


\subsection{Cropping intensity}

Among all the haor districts, the proportion of single cropped area is the highest (44\%) in Sunamgonj and due to that the cropping intensity in that district stands at the lowest (143\%) (Table $2)$. On the contrary, the proportion of triple cropped area is the highest (with lowest single cropped area ) in Kishoreganj that led to have highest cropping intensity (215\%), which is higher than the national average cropping intensity of $178 \%$ (HAS, 2008). However, in case of B. Baria, the proportion of both double and triple cropped areas are moderately higher and that led to have better cropping intensity (189\%). The cropping intensity in the haor area could be increased if attempts taken in improving the cropping practices for the single and double cropped areas.

\subsection{Seasonal land distribution for rice production in the haor areas}

Winter Boro is the main crop in haor areas and majority of the crop lands are devoted for irrigated bor production. Among the seven haor districts under consideration, probably crop land in Kishoregonj are more suitable for MV Boro rice production and the level of adoption of MV Boro is the highest (94\%) in this district (Table 3). Like wise, in Habigonj also the area devotion to modern boro rice is impressive and the coverage of MV boro area was about $87 \%$ (Table 3).

Table 3. Area coverage (000 ha) under different crops by season in the haor areas

\begin{tabular}{l|c|c|c|c|c}
\hline \multicolumn{1}{c|}{ District } & Aus & Aman & Boro & $\begin{array}{c}\text { Total cropped } \\
\text { area }\end{array}$ & $\begin{array}{c}\text { \% of area under each } \\
\text { haor districts }\end{array}$ \\
\hline Sunamgonj & - & - & $135.89(63)$ & 136 & 30 \\
Kishoregonj & - & - & $117.15(94)$ & 117 & 26 \\
Netrokona & $4.88(89)$ & $40.56(50)$ & $45.98(62)$ & 90 & 20 \\
Sylhet & - & $19.65(2)$ & $14.10(60)$ & 34 & 7 \\
Hobigonj & - & 10.00 & $33.00(87)$ & 43 & 10 \\
Mov. Bazar & $0.29(72)$ & $6.71(3)$ & $10.28(70)$ & 17 & 4 \\
B. Baria & - & - & $14.12(72)$ & 14 & 3 \\
Total & $4.19(83)$ & $76.92(27)$ & $358.38(73)$ & 452 & 100 \\
\hline
\end{tabular}

(Source: DAE) Figures in the parentheses indicate percent area under MVs

Table 4. Adoption level of different modern boro varieties in the haor areas of Bangladesh

\begin{tabular}{l|l|l|c|c|c|c}
\hline \multirow{2}{*}{ Districts } & \multicolumn{7}{c}{ Variety/ percent area covered } \\
\cline { 2 - 7 } & BR14 & BR19 & $\begin{array}{c}\text { BRRI dhan } \\
28\end{array}$ & BRRI dhan29 & Others & Hybrid \\
\hline Sunamgonj & $5(4)$ & $15(20)$ & $15(17)$ & $43(45)$ & $22(12)$ & $-(2.0)$ \\
Kishoregonj & $14(12)$ & $4(5)$ & $12(16)$ & $49(53)$ & $20(11)$ & $0.24(3.0)$ \\
Netrokona & $14(10)$ & $6(7)$ & $20(25)$ & $40(42)$ & $18(16)$ & $0.10(2.0)$ \\
Sylhet & $11(10)$ & $13(18)$ & $21(19)$ & $22(23)$ & $31(30)$ & $0.34(1.0)$ \\
Habigonj & $3(3)$ & $7(9)$ & $14(12)$ & $52(55)$ & $24(19)$ & $0.12(2.0)$ \\
Mov. Bazar & $6(5)$ & $19(15)$ & $28(34)$ & $27(31)$ & $20(14)$ & $-(1.0)$ \\
B. Baria & $6(6)$ & $12(10)$ & $27(24)$ & $40(43)$ & $15(16)$ & $0.14(1.0)$ \\
\hline
\end{tabular}

Huda, 2004; and Field survey, 2008] Figures in the parentheses are the findings of field survey 2008-09. 
In the haor areas of Sunamgonj, Kishoregonj, Sylhet and Hobigonj, rice is not grown in Aus season. (DAE, 2007). Similarly, in Aman season also rice is not grown profusely in the haor areas of Sunamgonj, Kishoregonj and B.Baria. On the other hand, in Netrokona and Moulavibazar haor areas, about 89 and $72 \%$ of the total Aus areas, respectively were devoted to modern rice varieties. These results confirm the findings of some earlier studies, (BRRI, 2004; Elahi et al., 1999)

\subsection{Adoption and yield of modern rice varieties}

The changing scenario of varietal adoption in haor areas over the years has been presented in (Table 4). It appears from the analysis that, the level of adoption of BR14 has decreased in 2008, while the acreage under BRRI dhan 28 and BRRI dhan 29 increased in the haor areas in most of the districts during the years 2004 to 2008. It is important to note that, BR19 has been becoming a bit more popular in some of the haor areas and the coverage of this variety was more in Sunamgonj, Sylhet, and Hobigonj areas in the Boro season. The area under BRRI dhan 28 and 29 in Moulavibazar increased substantially in 2008 over the year 2004. However, the adoption of BRRI dhan 29 was the highest in Habiganj haor area. The adoption of hybrid rice varieties had an increasing trend in almost all the haor districts

Table 5. Level of farmers' achieved yield ( $\mathrm{t} / \mathrm{ha}$ ) of rice in the haor areas

\begin{tabular}{l|c|c|c|c|c}
\hline \multirow{2}{*}{ District } & \multicolumn{3}{|c}{ Yield (t/ha) } \\
\cline { 2 - 6 } & \multirow{2}{*}{ Aus } & \multicolumn{2}{|c}{ Aman } & \multicolumn{2}{c}{ Boro } \\
\cline { 3 - 6 } Sunamgonj & - & B. Aman & MV & MV & Hybrid \\
Kishoregonj & - & - & - & $4.33(2.39)$ & 5.50 \\
Netrokona & $3.03(2.38)$ & 2.39 & $4.33(2.58)$ & $5.37(2.24)$ & 5.82 \\
Sylhet & - & 2.19 & $4.25(2.88)$ & $4.33(2.46)$ & 5.65 \\
Hobigonj & - & 1.84 & - & $4.93(2.39)$ & $5.45-$ \\
Mov. Bazar & $3.10(1.36)$ & 2.13 & $4.09(2.24)$ & $4.10(2.24)$ & 5.78 \\
B. Baria & $3.12(1.68)$ & 2.22 & $4.23(2.45)$ & $4.85(2.54)$ & 5.92 \\
\hline
\end{tabular}

Figures in the parentheses indicate yield of LV rice

Table 6. Comparative input use scenario for modern and traditional Boro rice cultivation at the farm level in haor areas.

\begin{tabular}{lcccc}
\hline \multicolumn{1}{c}{ Inputs used } & MV Boro & LV Boro & Increase in input use over LV (\%) \\
\hline Human labor (mandays/ha) & 170 & 112 & 52 \\
Animal labor (hr/ha) & 50 & 39 & 28 \\
Power Tiller (hr/ha) & 10 & 6 & 67 \\
Seeds (kg/ha) & 55 & 52 & 6 \\
\hline Fertilizer: & & & 123 \\
\hline Urea & 145 & 65 & 114 \\
TSP & 30 & 14 & 150 \\
MP & 20 & 8 &
\end{tabular}


Usually, farmers grow MV T. Aus and T. Aman in comparatively higher elevated lands at the side or end of the haor ( locally called 'kanda'). The yield of MV T. Aman was the highest (4.33 t/ha) in Netrokona haor areas followed by Sylhet area (4.25 t/ha) (Table 5). On the other hand, the yield of MV Boro was the highest (5.37 t/ha) in Kishoregonj haor area followed by Netrokona area $(5.07 \mathrm{t} / \mathrm{ha})$. Hybrid rice was grown in the haor areas under all the sample districts. However, the estimated highest yield of hybrid rice was obtained by the sample farms under Netrokona haor areas (6.72 t/ha).
Farmers in the deep haor area grew traditional rice varieties in the Boro season and applied less amount of inputs for LV Boro rice. There was a substantial difference in labour use between MV Boro and LV boro production. The use of human labor for MV Boro production was almost $52 \%$ higher compared to that for LV Boro (Table 6). The cost of land preparation by power tiller was $67 \%$ less in case of LV Boro rice compared to that of MV Boro rice cultivation. It is due to the fact that in majority cases LV Boro is grown in the deep basin areas some times under zero tillage.

Table 7. Cost (Tk./ha) of Boro cultivation in the haor areas

\begin{tabular}{l|c|c|c|c}
\hline \multirow{2}{*}{\multicolumn{1}{c}{ Cost items }} & \multicolumn{2}{|c|}{ MV } & \multicolumn{2}{c}{ LV } \\
\cline { 2 - 5 } & $\begin{array}{c}\text { Cost } \\
\text { (Tk./ha) }\end{array}$ & \% of total cost & $\begin{array}{c}\text { Cost } \\
\text { (Tk./ha) }\end{array}$ & \% of total cost \\
\hline Cost of land preparation & 4563 & 7.62 & 2600 & 7.35 \\
Seeds/seedlings & 2471 & 4.12 & 2012 & 5.69 \\
Pre-harvest labor & 9943 & 16.59 & 7200 & 20.36 \\
Harvest and post harvest & 16755 & 27.96 & 9824 & 27.78 \\
labor & 4171 & 6.96 & 1240 & 3.51 \\
Fertilizer cost & 9699 & 16.19 & 2462 & 6.96 \\
Irrigation and insecticides & 1197 & 2.00 & 562 & 1.59 \\
Interest on operating capital & 11120 & 18.56 & 9458 & 26.75 \\
( @ 10\% ) & 59919 & 100 & 35358 & 100 \\
Land rent & Full cost basis & & &
\end{tabular}

Table 8. Cost and returns (Tk./ha) for Boro rice cultivation in the Haor areas

\begin{tabular}{lcc|c|c}
\hline $\begin{array}{c}\text { Cost and returns } \\
\text { items }\end{array}$ & MV & LV & $\begin{array}{c}\text { Difference } \\
\text { (in \% })\end{array}$ & $\mathrm{P}=(\mathrm{T}<\mathrm{t})$ \\
\hline Yield (kg/ha) & 5532 & 3096 & 79 & 0.001 \\
Gross returns & 102342 & 56276 & 82 & 0.000 \\
Production cost & 59919 & 35358 & 74 & 0.002 \\
Gross margin & 59151 & 26544 & 123 & 0.000 \\
Net returns & 42423 & 20918 & 103 & 0.000 \\
BCR & 1.71 & 1.59 & 8 & 0.002 \\
\hline
\end{tabular}




\subsection{Cost and return in rice production in the haor areas}

The cost of land preparation for MV Boro rice production was Tk 4563/ha which is almost double than that of LV Boro production (Table 7). The fertilizer cost for MV Boro was three times higher than that of LV Boro rice. Irrigation cost shared about $17 \%$ of the total cost of MV Boro production while in case of LV Boro production the share of irrigation was only $7 \%$. On an average, the gross return of MV Boro rice was Tk. 102342 /ha which was almost $82 \%$ higher than that of LV (Table 8). However, the cost of MV Boro production was almost $74 \%$ higher compared to that of LV Boro rice, while the gross margin and net returns were respectively 123 and $103 \%$, higher than those of LV Boro rice. These findings are in consonance with that of an earlier study (Harun and Alam, 1996).

\subsection{Existing and potential cropping pattern}

The scenario of cropping patterns practiced by the sample farms in different haor areas are presented in Table 9. In Sunamgonj and Kishoreganj, 80 and $82 \%$ area, respectively, were covered by Boro-Fallow-Fallow pattern. Similarly, in Netrokona and B. Baria, 78 and $72 \%$ of the total haor areas were covered by this pattern. This findings further implies that, a vast area of those haor districts are devoted for single cropping which eventually leads to low level of cropping intensity. On the other hand, the single cropping pattern covered less than $70 \%$ haor areas under Sylhet, Hobigonj and Moulavibazar indicating that there are other cropping patterns practiced in those areas and there is ample scope of increasing the improved cropping patterns there. Data in Table 10 indicate that, in the haor areas under all the seven districts, some other crops such as vegetable, mustard, ground nut, wheat, chilly etc. can be grown at the side of the haor (named 'kanda'). As instance, in the 'Summon haor' area of sunamganj, FallowFallow-T. Aman pattern is practiced over $3 \%$ of the total area; but about $90 \%$ of this area may be brought under the pattern of Rabi crop (mustard)- Fallow-T. Aman, which would be an added option over the existing cropping pattern. At the same breath, in the haor areas of Moulavibazar, about $7 \%$ areas are devoted to Fallow-Aus-T. Aman pattern, but $80 \%$ of this area could be brought under Rabi crop-Aus-T. Aman pattern since few farms have taken initiatives and were practicing this pattern in order to harness the exploitable benefit out of this potential pattern.

Table 9. Major Cropping patterns practiced in different haor areas under study: 2008

\begin{tabular}{|c|c|c|c|}
\hline District & Pattern -1 & Pattern-2 & Pattern-3 \\
\hline Sunamgonj: & $\begin{array}{c}\text { Boro-Fallow-Fallow } \\
\text { (86) }\end{array}$ & Fallow-B.Aman-Fallow (2) & Fallow-Wheat-Fallow (2) \\
\hline Kishoregonj & $\begin{array}{l}\text { Boro-Fallow-Fallow } \\
(82)\end{array}$ & Wheat-Fallow-Fallow (3) & G. nut-Fallow-Fallow (2) \\
\hline Netrokona & $\begin{array}{c}\text { Boro-Fallow-Fallow } \\
\text { (78) }\end{array}$ & Mustard-Fallow-Fallow (6) & Boro-Fallow-.T.Aman (9) \\
\hline Sylhet & $\begin{array}{c}\text { Boro-Fallow-Fallow } \\
(60)\end{array}$ & $\begin{array}{c}\text { Fallow-B.Aman-Fallow } \\
(21)\end{array}$ & $\begin{array}{c}\text { Fallow- Fallow- T.Aman } \\
(4)\end{array}$ \\
\hline Hobigonj & $\begin{array}{c}\text { Boro-Fallow-Fallow } \\
(68)\end{array}$ & Boro-B.Aman-Fallow (8) & $\begin{array}{l}\text { B.Aman-Fallow-Fallow } \\
\text { (12) }\end{array}$ \\
\hline M. Bazar & $\begin{array}{c}\text { Boro-Fallow-Fallow } \\
\text { (64) }\end{array}$ & $\begin{array}{l}\text { Fallow-B.Aman-Fallow } \\
(18)\end{array}$ & Fallow-Aus-T..Aman (7) \\
\hline B.Baria & $\begin{array}{l}\text { Boro-Fallow-Fallow } \\
\text { (72) }\end{array}$ & Fallow-B.Aman-Fallow (6) & Boro-Fallow-.T.Aman (5) \\
\hline
\end{tabular}

[Source: DAE, (Huda, 2004) and Field survey, 2008]

Figures in the parentheses indicate percent of the total area of the patterns 
Table 10. Possible cropping patterns in the haor areas

\begin{tabular}{|c|c|c|c|}
\hline Major existing cropping patterns & $\begin{array}{l}\% \text { Area under } \\
\text { the pattern }\end{array}$ & Possible cropping patterns & $\begin{array}{l}\text { Exploitable } \\
\text { area under } \\
\text { pattern }(\%)\end{array}$ \\
\hline \multicolumn{4}{|l|}{ Sunamgonj: } \\
\hline Boro-Fallow-Fallow & 80 & - & - \\
\hline Fallow-Fallow-T.Aman & 3 & Rabi crop-Fallow-T.Aman & 90 \\
\hline Boro-Fallow-T.Aman & 8 & - & - \\
\hline Fallow-Aus-T.Aman & 6 & Vege.-Aus-T.Aman & 50 \\
\hline \multicolumn{4}{|l|}{ Sylhet: } \\
\hline Boro-Fallow-Fallow & 60 & - & - \\
\hline Fallow-Fallow-T.Aman & 10 & Rabi crops-Fallow-T.Aman & $70-80$ \\
\hline Boro-Fallow-T.Aman & 21 & - & - \\
\hline Fallow-Fallow-B.Aman & 5 & Rabi crops-B.Aman & 100 \\
\hline \multicolumn{4}{|l|}{ Hobigonj: } \\
\hline Boro-Fallow-Fallow & 68 & Boro-Fallow-T.Aman & 30 \\
\hline Boro-B.Aman-Fallow & 8 & - & - \\
\hline B.Aman-Fallow-Fallow & 12 & - & \\
\hline \multicolumn{4}{|l|}{ Netrokona: } \\
\hline Boro-Fallow-Fallow & 82 & Boro-Fallow-T.Aman & 20 \\
\hline Mustard-Fallow-Fallow & 6 & Mustard-Boro-Fallow & 25 \\
\hline Boro-Fallow-.T.Aman & 9 & - & - \\
\hline \multicolumn{4}{|l|}{ Kishoregonj: } \\
\hline Boro-Fallow-Fallow & 82 & - & - \\
\hline Wheat-Fallow-Fallow & 3 & Wheat-B.Aman-Fallow & 70 \\
\hline Ground nut-Fallow-Fallow & 2 & Ground nut- B.Aman-Fallow & 40 \\
\hline \multicolumn{4}{|l|}{ Moulavibazar: } \\
\hline Boro-Fallow-Fallow & 64 & Boro-Fallow-T..Aman & 20 \\
\hline Fallow-B.Aman-Fallow & 18 & Rabi crops-B.Aman-Fallow & 45 \\
\hline Fallow-Aus-T..Aman & 7 & Rabi crops-Aus-T..Aman & 80 \\
\hline \multicolumn{4}{|l|}{ B.Baria: } \\
\hline Boro-Fallow-Fallow & 72 & Boro-Fallow-T.Aman & 10 \\
\hline Fallow-B.Aman-Fallow & 6 & Rabi crops-B.Aman-Fallow & 76 \\
\hline Boro-Fallow-.T.Aman & 5 & - & - \\
\hline
\end{tabular}

[Source: DAE and Field survey 2008] 
Table 11. Farmers' stated constraints to MV rice cultivation in the haor areas

\begin{tabular}{lll}
\hline Sl.no. & \multicolumn{1}{c}{ Stated constraints } & $\%$ farmers opined \\
\hline 1. & Lack of adequate amount of MV seeds & 65 \\
\hline 2. & Lack of short duration modern varieties of seeds & 78 \\
\hline 3. & High price of inputs & 86 \\
\hline 4. & Labor shortage at the time of harvest & 56 \\
\hline 5. & Hauling of Boro paddy & 43 \\
\hline 6. & More post harvest loss due to heavy rainfall & 32 \\
\hline 7. & Threshing, drying and storing problem due to excessive rainfall & 65 \\
\hline 8. & Farmers do not get fair price & 40 \\
\hline 9. & Lack of integration with other different organization & 15 \\
\hline 10. & Early flash flood and lack of water control & 72 \\
\hline 11. & Problem of carrying paddy from the field due to kacha road & 80 \\
\hline NB: Muliple responses conidered
\end{tabular}

NB: Multiple responses considered

\subsection{Constraints to crop production}

The farm level constraints as observed and opined by the sample respondents are summarized in Table 11. The most vital constraint in the haor areas is high price of inputs (fertilizer, seed, labor etc.) and this was opined by $86 \%$ of the sample farmers. Transportation of the output (e.g. paddy) after harvesting also appeared to be a major problem since in most areas the roads are non-metal 'kacha' roads and $80 \%$ farmers reported about this constraint (Table 11). Lack of short duration modern varieties as a constraint was mentioned by most of the sample farms. Since early flash flood causes severe crop loss in most of the years, plantation of early maturing (short duration) rice variety would enable farmers to escape crop damage from early flash flood. Lack of water control dam also appeared to be an important problem in the haor areas.

\section{Conclusions}

The haor areas under seven selected districts of Bangladesh covered almost 0.68 million hectares of land of which $66 \%$ area is devoted to crop cultivation. In the haor areas of Sunamgonj and Kishoregonj, more than $80 \%$ of the total cropped areas were covered by Boro-Fallow-Fallow cropping pattern. In most of the haor areas BRRI dhan 28 and 29 were the prominent Boro varieties. Farmers in the haor areas applied lower amounts of fertilizers than the recommended rate, possibly because of better soil fertility. The cost of production for MV Boro was almost double than that of $\mathrm{LV}$ rice. The yield of MV Boro was almost $79 \%$ higher than that of $\mathrm{LV}$ Boro. Similarly, the return from MV boro was about $82 \%$ higher than that of LVs. Rabi Fallow- T. Aman, Vegetable-Aus-T. Aman and Rabi -B. Aman patterns emerged as the potential cropping patterns in the haor areas and these would help increase both cropping intensity and productivity in those areas. Higher price of inputs, lack of short duration modern rice variety and lack of flood control dam were the major constraints to modern rice production in the haor areas. Availability of short duration MV seeds and development of physical infrastructure as 
well as availability of different agricultural machineries such as power tiller, irrigation equipment, threshing machines, drying machines etc. could be immensely useful for horizontal expansion of cropped area in the haor areas of Bangladesh which would eventually increase the level of food productivity in the country.

\section{References}

Bangladesh Bureau of Statistics (BBS), 2007. Statistical Year book of Bangladesh. Statistics Division, Ministry of Planning. Government of the People's Republic of Bangladesh

Bangladesh Rice Research Institute (BRRI), 2004. Twentieth National Workshop on Rice Research and Extension in Bangladesh. Emerging Technologies for Sustainable Rice Production. Bangladesh Rice Research Institute, Gazipur-1701. 1921 April 2004.

Department of Agricultural Extension (DAE), 2007. Department of Agricultural Extension, Field Crops wing, Khamar Bari, Farmgate, Dhaka-1215.

Das, D. C. 2004. Experience with Modern and Hybrid Rice varieties in plain land Ecosystem in the Mymensingh Region. Proceedings on Twentieth National Workshop on Rice Research and Extension in Bangladesh. Bangladesh Rice Research Institute. Gazipur-1701, 19-21 April 2004.

Elahi, N. E, Khan, A. H., Siddique, M. R., Shah, A. Nasim, M. and Shahidullah, S. M.
1999. Existing Cropping Patterns of Bangladesh, Potential Technologies and Strategies for Improving Systems Productivity. Proceedings of the Workshop on Modern Rice Cultivation in Bangladesh. February 14-16, pp.107-171.

Hand book of Agricultural Statistics (HAS), 2007. Ministry of Agriculture, AgroEconomic Research Unit, Government of the People's Republic of Bangladesh. Dhaka, December, 2007.

Harun. M. E., and Alam, M. S. 1996. Economic Effect of Changing B. Aman Areas into Boro Rice in Bangladesh. Bangladesh Journal of Agricultural Research, 20 (1):183-189.

Huda, M. K. 2004. Experience with modern and hybrid rice varieties in haor ecosystem: Emerging Technologies for Sustainable Rice Production. Twentieth National Workshop on Rice Research and Extension in Bangladesh. Bangladesh Rice Research Institute. Gazipur-1701, 19-21 April 2004.

Husain A. M, Hossain, M. and Janaiah, A. 2001. Hybrid Rice Adoption in Bangladesh: A Socio-economic Assessment of Farmers' Experiences, Research Report, Social Sciences Division, International Rice Research Institute (IRRI), LosBanos, Philippines.

Jabber M. A. and Alam, M. S. 1993. Adoption of Modern Rice Varieties in Bangladesh. The Bangladesh Journal of Agricultural Economics, 16(2): 77-95. 